\title{
MEMBANGUN INTERAKSI EDUKATIF YANG BERNILAI NORMATIF MELALUI PENGAJARAN BERBASIS AKTIFITAS
}

\author{
HAWA LIBERNA \\ Program Studi Pendidikan Matematika, Fakultas Teknik, Matematika dan IPA \\ Universitas Indraprasta PGRI
}

\begin{abstract}
Abstrak. Untuk memecahkan masalah ketertarikan siswa pada matematika, diperlukan suatu model pembelajaran yang interaktif dan tidak membosankan. Penting untuk membangun interaksi edukatif, dan salah satunya dapat dilakukan dengan pengajaran berbasis aktifitas. Belajar berorientasi aktifitas merupakan penelitian tindakan kelas, dan merupakan penelitian reflektif yang dilaksanakan di dalam kelas, serta bertujuan untuk meningkatkan kualitas pembelajaran. Proses ini diterapkan dengan "papan berpaku" untuk berlatih, baik oleh guru dan siswa secara kolektif. Peran guru hanya untuk respon yang berkaitan dengan geometri seperti bangun datar dan persegi. Evaluasi ini dimulai dengan mempersiapkan rencana pelaksanaan pembelajaran tematik dengan standar kompetensi dalam menghitung keliling bangun datar, luas persegi dan persegi panjang, serta aplikasi dan pemecahan masalah.
\end{abstract}

Kata kunci: belajar berorientasi aktifitas, papan dengan kuku, penelitian tindakan kelas.

\begin{abstract}
To solve the problem of students' interest in mathematics, we need a model of interactive learning and not boring. It is important to establish educational interactions, and one of them to do with the activity-based teaching. Learning is an activity-oriented action research and reflective study is conducted in the classroom, as well as aiming to improve the quality of learning. This process is applied to the "boards nailed" to practice, both by teachers and students collectively. The teacher's role is only to the response associated with the wake geometry as flat and square. This evaluation starts with preparing the implementation plan thematic learning with competency standards in the wake circumference flat, square and rectangular wider, as well as applications and problem solving.
\end{abstract}

Keywords: learning-oriented activities, boards with nails, classroom action research.

\section{PENDAHULUAN}

Belajar dapat diartikan sebagai perubahan tingkah laku pada diri individu dan berkat adanya interaksi antara individu dengan lingkungan sehingga mereka lebih mampu berinteraksi dengan lingkungannya. Lingkungan belajar di sekolah khususnya sekolah dasar perlu memperkuat dasar belajar yang kuat dalam segala bidang studi khususnya bidang studi matematika.

Bidang studi ilmu exsacta seperti matematika biasanya pelajaran yang tidak semua siswa dapat dengan mudah memahaminya. Terkadang menjadi hal yang paling ditakutkan dan kurang diminati dibandingkan dengan bidang studi lainnya. Atas dasar inilah, hasil belajar atau nilai matematika siswa sering lebih rendah dibandingkan dengan bidang studi lainnya. 
Untuk mengatasi daya minat dan keinginan untuk belajar matematika, guru harus memiliki cara atau model belajar yang tidak bersifat monoton tetapi harus bersifat dinamis sehingga bisa merespon minat dan keinginan siswa untuk belajar matematika. Respon minat dan keinginan belajar matematika yang positif bisa menghasilkan tidak saja nilainya tetapi juga dapat lebih dimengerti dan dipahami. Proses belajar itu dilakukan melalui pembelajaran berbasis aktivitas.

Pembelajaran berbasis aktivitas adalah perubahan perilaku belajar yang mendorong rasa ingin tahu yang tinggi atas bidang studi ilmu eksata tersebut termasuk matematika. Siswa yang belajar matematika memiliki tujuan yang ingin dicapai pertama mengerti dan memahami matematika yang diiringi dengan pencapaian nilai matematika lebih baik dengan mata pelajaran lainnya. Mengerti memahami matematika atas cara dan bentuk penyelesaian matematika secara mudah dan sederhana.

Namun kenyataan di lapangan, jarang sekali guru memanfaatkan media pembelajaran yang relevan untuk pembelajaran Matematika. Proses pembelajaran aktivitas dilakukan dengan Penelitian Tindakan Kelas (PTK), guru belum memanfatkan media pembelajaran matematika dengan materi Pencerminan karena hasil belajar matematika siswa cenderung kurang maksimal.

Alat peraga merupakan salah satu unsur peralatan dari media pembelajaran. Saat kegiatan belajar mengajar matematika, alat peraga merupakan suatu bagian yang disatukan dalam penyajian pelajaran untuk mencapai tujuan pelajaran secara umum. Alatalat peraga ini dapat mendekati realitas, agar dapat mencerminkan sebuah bangun datar sulit dimengerti siswa. Alat peraga juga dapat membantu meningkatkan dan merangsang minat belajar dari sebuah kelas yang apatis. Alat peraga mempunyai hubungan nilai hiburan dan tidak memperkecil arti pokok pelajarannya, tetapi menjadi sarana untuk membantu memperjelas pelajaran matematika dengan materi "pencerminan"

Tujuan utama penggunaan alat peraga papan berpaku adalah agar konsep dan ide dalam matematika yang sifatnya abstrak dapat dikaji, dipahami dan dicapai oleh penalaran siswa, terutama siswa yang masih memerlukan bantuan alat yang sifatnya nyata dan terlihat dengan jelas dalam menangkap konsep-konsep matematika yang diajarkan. Setiap alat peraga papan berpaku yang digunakan guru matematika dalam proses pembelajaran harus berdasarkan tujuan instruksional yang telah disusun. Artinya, alat peraga yang digunakan harus sesuai dengan materi pelajaran yang akan diajarkan oleh guru.

Alat peraga yang akan digunakan dalam penelitan tindakan kelas yaitu alat peraga papan berpaku. Alat peraga papan berpaku merupakan media pembelajaran matematika yang relevan dengan materi pengenalan konsep bangun datar, keliling dan luas bangun datar. Alat peraga papan berpaku terbuat dari papan berbentuk persegi panjang atau bujur sangkar yang di atasnya ditancapkan paku-paku yang tersusun sesuai ukuran tertentu. Pada alat peraga papan berpaku, guru dapat mencari berbagai panjang ruas garis, baik berupa bilangan bulat dan pecahan. Selain itu, guru juga dapat menghitung luas berbagai daerah yang bentuknya tidak beraturan melalui perkiraan hasil yang mendekati.

Keunggulan dari papan berpaku adalah alat ini menyajikan bentuk geometri yang lebih dekat kepada kenyataan daripada kertas atau semacamnya. Alat peraga ini cocok untuk membantu siswa dalam mengenali berbagai macam bentuk bangun datar, sehingga siswa akan lebih memahami hasil pencerminan dari bentuk bangun datar tersebut karena bisa melihat secara real.

Adapun hal yang mendasari peneliti untuk menggunakan alat peraga papan berpaku yaitu peneliti memperoleh beberapa temuan permasalahan saat proses pembelajaran, yaitu: Penjelasan guru yang terlalu cepat, Guru tidak memberikan contoh konkrit pada bangun datar, Guru tidak memanfaatkan alat peraga ketika pembelajaran 
bangun datar, Guru tidak memberikan kesempatan untuk siswa menemukan sendiri hasil hasil dari pencerminan, Guru tidak bisa memberikan konsep sama antara siswa satu dengan lainnya, Hasil pencerminan antar satu siswa dengan lainnya berbeda

Berdasarkan analisis masalah di atas, maka pengajaran berbasis aktivitas difokuskan pada Penelitian Tindakan Kelas (PTK) mata pelajaran matematika adalah upaya meningkatkan pemahaman konsep sekolah dengan menggunakan alat peraga papan berpaku. Oleh karena itu, rumusan masalah dari permasalahan di atas adalah "Apakah penggunaaan alat peraga papan berpaku sebagai bentuk interaksi edukatif bernilai normatif melalui pengajaran berbasis aktivitas dapat meningkatkan pemahaman konsep Siswa dalam Mata Pelajaran Matematika"

\section{PEMBAHASAN}

\section{Minat Belajar}

Minat adalah salah satu faktor psikologis yang mempengaruhi belajar seseorang. Menurut pengertian yang bersifat umum yang dimaksud dengan minat adalah suatu keadaan mental yang menghasilkan respon terarah kepada situasi tertentu yang menyenangkan dan memberi kepuasaan. Menurut Dewa Ketut Sukardi (2008:61) Minat merupakan suatu kesukaan, kegemaran, kesenangan akan sesuatu

Pada hakikatnya minat adalah penerimaan akan suatu hubungan antara diri sendiri dengan sesuatu yang terdapat di luar diri sendiri. Semakin kuat hubungan tersebut, semakin besar minat. Dengan adanya minat dalam diri individu, akan menjadikan belajar sebagai suatu kegiatan yang menyenangkan dan pada akhirnya akan memberikan kepuasan pada dirinya.

Hurlock (2007: 114) mengatakan: "Minat merupakan suatu motivasi yang mendorong individu untuk melakukan kegiatan yang dipilihnya bila mereka melihat sesuatu akan memberikan manfaat, mereka akan memperoleh kepuasaan dan akan berminat pada hal itu, tetapi jika kepuasaan berkurang, minatnya pun akan berkurang." Mengembangkan minat siswa pada pelajaran pada dasarnya adalah membantu siswa melihat bagaimana hubungan antara materi yang diharapkan untuk dipelajarinya dengan dirinya sendiri sebagai individu. Proses ini berarti menunjukkan pada siswa bagaimana pengetahuan atau kecakapan tertentu mempengaruhi dirinya, melayani tujuan-tujuannya, memuaskan kebutuhan-kebutuhannya. Bila siswa menyadari bahwa belajar merupakan suatu alat untuk mencapai beberapa tujuan yang dianggapnya penting, dan bila siswa melihat bahwa hasil dari pengalaman belajarnya akan membawa kemajuan pada dirinya, kemungkinan besar ia akan berminat untuk mempelajarinya (Slameto, 2007: 180).

Dalam mendorong minat belajar siswa karena faktor pembiasaan dalam perilaku belajar. Contoh: siswa belajar matematika yang keliru akhirnya terbiasa dengan penggunaan rumus dan angka dan alur penyelesaian soal yang benar. Disamping itu juga diperlukan berpikir asosiatif dan daya ingat. Karena berpikir asosiatif bisa membentuk respon kemampuan siswa untuk merespon apa yang dilihat di depannya. Respon tersebut bisa memberikan dorongan mengenai rumus dan kecepatan dalam proses operasi perkalian, pertambahan, pengurangan dan pembagian. Dorongan ini timbul harus ada ditimbulkan dari respons terlebih dahulu karena tanpa respons, pola pemikiran asosiatif. Justru dengan pemikiran asosiatif, bisa menciptakan daya ingat kuat. Hal inilah yang harus menjadi faktor kebiasaan siswa guna mendorong minat untuk belajar matematika. Beberapa ahli pendidikan berpendapat bahwa cara yang paling efektif untuk membangkitkan minat belajar pada suatu subyek yang baru adalah dengan menggunakan minat-minat siswa yang telah ada.

Disamping memanfaatkan minat yang telah ada, Tanner dan Tanner (1975) dalam Slameto (2008:180) menyarankan agar para pengajar juga berusaha membentuk minat 
baru pada diri siswa. Setelah timbul minat belajar pada diri siswa terhadap suatu mata pelajaran, maka siswa akan berupaya untuk mencapai hasil yang diharapkan.

Minat belajar berkembang harus disertai dengan motivasi guru, bakat dan kecerdasan. Guru yang berhasil mengembangkan perilaku belajar siswa melalui berbagai cara yang sederhana dan mudah dipahami sehingga keinginan belajar murid berkembang disertai rasa ingin tahu tinggi. Berdasarkan uraian tersebut dapat diketahui bahwa Minat belajar dapat ditandai dengan adanya ketertarikan, kesenangan, keinginan, dalam mempelajari hal-hal baru yang dianggap menyenangkan dan cenderung memberikan reaksi positif terhadap hal yang ada dari luar diri.

\section{Konsep Belajar}

Pengertian belajar yang diungkapkan oleh para ahli intinya dalam belajar terjadi perubahan yang mempengaruhi tingkah laku seseorang. Ini sesuai yang diungkapkan oleh Djamarah (2008:13) bahwa belajar adalah serangkaian kegiatan jiwa raga untuk memperoleh suatu perubahan tingkah laku sebagai hasil pengalaman individu dalam interaksi dengan lingkungannya yang menyangkut kognitif, afektif dan psikomotor.

Setiap usaha pasti menginginkan adanya hasil yang ingin dicapai, termasuk hasil belajar. Seseorang yang belajar mempunyai tujuan yang ingin dicapai dari belajar itu sendiri. Misalnya, dari tidak tahu menjadi tahu, dari tidak tahu menjadi bisa, dari tidak mengerti menjadi tidak mengerti dan tujuan lainnya sesuai dnegan keinginan individu sendiri. Menurut Purwanto (2010:54) bahwa hasil belajar adalah perubahan perilaku yang terjadi setelah mengikuti proses belajar mengajar sesuai dengan tujuan pendidikan. Sedangkan menurut Setiawati dan Chudari (2007:70) mengungkapkan bahwa "belajar sesuatu sebagai hasilnya ia akan mengalami perubahan tingkah laku secara menyeluruh dalam sikap, kebiasaan, keterampilan, pengetahuan, dan sebagainya" Jadi hasil belajar dapat dikatakan hasil yang diperoleh individu yang telah mengikuti proses belajar mengjajar sesuai dengan tujuan yang ingin dicapai individu tersebut.

\section{Konsep Alat Peraga Papan Berpaku}

Pada dasarnya anak akan lebih memahami pelajaran geometri jika guru menyajikannya melalui benda-benda nyata. Benda nyata digunakan sebagai alat bantu pengajaran matematika untuk membantu anak memahami materi pelajaran. Alat bantu pengajaran disebut alat peraga. Alat peraga yaitu alat untuk menerangkan atau mewujudkan konsep matematika (Ruseffendi, 2007:229). Menerangkan atau mewujudkan

Konsep matematika dapat dengan benda-benda yang ada disektiarnya, diantaranya: batu-batuan, kacang-kacangan untuk menerangkan konsep bilangan: kubus (bendanya) untuk menjelaskan konsep titik, ruas garis, daerah bujur sangkar, dan wujud dari kubus itu sendiri, benda-benda bilangan beraturan untuk menerangkan konsep pecahan, benda seperti cicin, gelang, permukaan gelas dan sebagainya untuk menerangkan konsep lingkaran dan lain sebagainya (Ruseffendi, 2007:229).

Begitu banyak alat peraga yang ada dapat dipergunakan sebagai alat peraga dalam pembelajaran matematika. Alat peraga juga dapat menggunakan benda yang sudah tidak terpakai lagi misalnya dua bekas pasta gigi dapat digunakan untuk menerangkan bangunan ruang balok.

Alat peraga yang dipakai dalam penelitian adalah alat peraga sederhana yang dapat dibuat guru. Untuk membuat alat peraga sederhana tersebut ada beberapa kriteria yang dipergunakan yang harus diperhatikan seperti yang dikemukakan Ruseffendi (2007: 230) adalah sebagai berikut: 1) dibuat dari bahan-bahan yang cukup kuat supaya tahan lama, 2) diusahakan bentuk atau warnanya menarik; 3) dibuat secara sederhana, mudah dikelola, dan tidak rumit; 4) ukurannya dibuat sedemikian rupa sehingga seimbang 
dengan ukuran fisik anak; 5) dapat menyajikan konsep matematika (bentuk nyata, gambar, diagram); 6) sesuai dengan konsep, misalnya bila membuat alat peraga segitiga berdaerah karton atau tripleks mungkin anak beranggapan bahwa segitiga itu bukan rusuk-rusuknya saja tetapi berdaerah, jelas ini tidak sesuai dengan konsep segitiga; 7) peragaan itu supaya merupakan dasar untuk timbulnya konsep abstrak; 8) bila diharapkan siswa belajar aktif (sendiri atau kelompok) alat peraga itu supaya dimanipulasikan yaitu dikutak katik seperti diraba, dipegang, dipindahkan atau dipasang dan dicopotkan, dan 9) bila memungkinkan buatlah alat peraga yang berfungsi banyak.

Untuk mendapatkan hasil baik dalam membuat alat peraga maka hal-hal tersebut harus diperhatikan secara seksama agar alat peraga dibuat dapat efektif menunjang dalam kegiatan pembelajaran matematika. Untuk memahami konsep abstrak anak memerlukan benda konkrit (riil) sebagai perantara visualisasi (Suherman, 2007: 203). Maka alat peraga merupakan salah satu peraturan atau visualisasi dari benda konkrit. Alat peraga dapat berupa benda konkrit dapat dipindah-pindahkan dan dimanipulasi. Oleh sebab itu berikut diuraikan fungsi alat peraga dalam pembelajaran matematika

Ada beberapa fungsi atau manfaat penggunaan alat peraga dalam pembelajaran matematika yang diantaranya: 1) dengan adanya alat peraga, anak-anak akan lebih banyak mengikuti pelajaran matematika semakin besar. Anak akan senang, terangsang, tertarik, dan bersikap positif terhadap pengajaran matematika, 2) dengan disajikan konsep abstrak matematika dalam bentuk konkrit, maka siswa pada tingkat tingkat yang lebih rendah akan lebih mudah memahami dan mengerti; 3) alat peraga dapat membantu daya tilik ruang, karena tidak membayangkan bentuk-bentuk geometri terutama geometri ruang sehingga dengan melalui gambar atau benda nyata akan membantu daya tiliknya sehingga lebih berhasil dalam belajarnya, 4) anak akan menyadari adanya hubungan antara pengajaran dengan benda-benda yang ada disekitarnya atau ilmu dengan alam disekitar dan masyarakat, 5) konsep abstrak yang tersajikan dalm bentuk konkrit yang dalam bentuk model matematika dapat dijadikan objek penelitian dan dapat pula dijadikan alat untuk penelitian ide-ide baru dan relasi baru (Ruseffendi, 2007:228).

Dari uraian di atas, alat peraga mempunyai banyak fungsi dalam pembelajaran matematika. Selain itu siswa dapat lebih memahami materi, alat peraga, yang juga dapat membantu guru dalam menyampaikan konsep matematika. Alat peraga matematika bermacam-macam salah satunya papan berpaku. Papan berpaku adalah papan yang diberikan paku banyak sekali manfaatnya untuk belajar matematika di tingkat Sekolah Dasar (SD), murah harganya dan dapat dibuat sendiri oleh guru. Alat peraga ini dibuat dari papan atau teakblok yang berbentuk persegi atau bujur sangkar Ruseffendi (2007:271)

Papan berpaku yang merupakan alat peraga sederhana dapat dibuat sendiri oleh guru maka pembuatannyapun tidak rumit. Cara pembuatannya adalah sebagai berikut: Pada papan ini dibuat bujur sangkar kecil yang ada pada setiap titik sudutnya ditancapkan paku setengahnya masuk dan setengah lagi masih tampak timbul. Papan berpaku sangat praktis baik untuk anak belajar maupun guru mengajar. Alat lain yang diperlukan adalah karet gelang (Ruseffendi, 2007:271) 


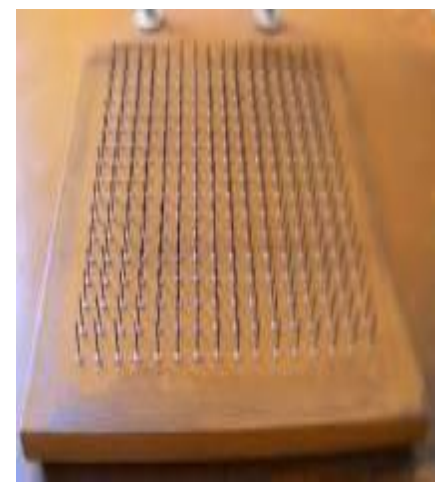

Gambar 1: Gambar Contoh Papan Berpaku

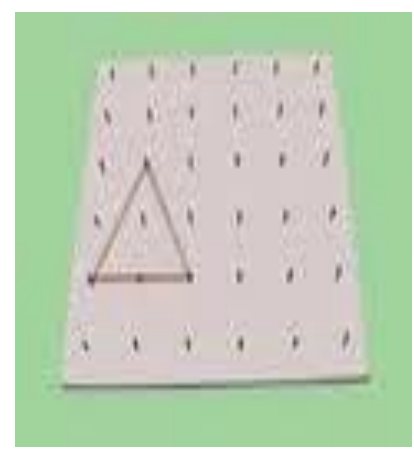

Gambar 2: Contoh Penggunaan Papan Berpaku

Selain mudah dan murah dalam pembuatannya, papan berpaku juga memiliki beberapa kegunaan seperti yang diungkapkan oleh (Ruseffendi, 2007: 271) menerangkan bahwa: beberapa faedah/kegunaan dari papan paku antara lain: 1) guru dapat dengan cepat menunjukkan bermacam-macam bentuk geometri bidang seperti segitiga, trapesium, dan sebagainya, 2) siswa dengan cepat pula mengikuti dalam membuat bangun-bangun geometri tanpa memerlukan banyak waktu untuk menggambar, tanpa memerlukan penghapus, penggaris, pensil dan kertas, 3) bentuk geometri yang terjadi lebih sesuai dengan sebenarnya daripada bila geometri itu disajikan dengan bangun geometri karton, tripleks, atau kertas lainnya sehingga tidak menyesatkan persepsi anak, 4) dapat dipakai untuk mencari berbagai panjang ruas garis baik yang bulat, pecahan maupun bilangan rasional, 5) dengan papan berpaku dapat pula menghitung luas berbagai daerah yang bentuknya tidak beraturan, dan 6) untuk memperagkan lingkaran dan diagram lingkaran dapat membuat papan berpaku berbentuk lingkaran.

Begitu banyak kegunaan papan berpaku tersebut, maka dapat disimpulkan bahwa alat peraga papan berpaku ini bisa untuk menjelaskan konsep bangun datar pada siswa.

\section{Implementasi}

Dalam mengimplementasikan pengajaran berbasis aktivitas yang salah satunya adalah pengajaran melalui konsep papan berpaku yang bertujuan untuk mendinamiskan proses belajar mengajar tindakan kelas (classroom action research) Penelitian tindakan kelas merupakan suatu bentuk penelitian bersifat reflektif yang dilakukan oleh pelaku dalam masyarakat sosial dan bertujuan untuk memperbaiki pekerjaannya dan memahaminya serta berusaha untuk meningkatkan menjadi lebih baik pekerjaan yang dilakukan. Penelitian kelas yang dilaksanakan di dalam kelas ketika pembelajaran 
berlangsung dilakukan yang bertujuan untuk meningkatkan kualitas pembelajaran. Penelitian tindakan kelas berfokus pada kelas atau proses pembelajaran yang terjadi di dalam kelas.

Dalam proses pembelajaran berbasis aktivitas melalui pengajaran papan berpaku dilakukan melalui beberapa tahap berikut ini:

1. Perencanaan

Perencanaan pertemuan Penelitian Tindakan Kelas setidak-tidaknya dua kali pertemuan. Namun demikian sebelum dilaksanakan penelitian tindakan kelas harus terlebih dahulu disusun Rencana Pelaksanaan Pembelajaran Tematik dengan menggunakan alat praga papan berpaku dengan standar kompetensi menghitung bangun datar keliling, luas persegi dan persegi panjang serta penggunaan dan pemecahan masalah. Kompetensi dasarnya adalah menghitung keliling persegi dan persegi panjang, soal-soal diberikan.

Selain menyusun Rencana Pelaksanaan Pembalajaran guru membuat alat peraga papan berpaku yang digunakan sebagai alat bantu untuk menentukan luas, keliling bangun datar persegi dan persegi panjang selain itu disusun pula Lembar Aktivitas Siswa yang diberikan dan alat evaluasi untuk mengetahui hasil pemahaman siswa pada setiap pertemuan.

Di samping menyusun Lembar Aktivitas Siswa dan alat evaluasi dilakukan pembagian kelompok. Setiap kelompok terdiri dari empat orang di mana siswa yang berkemampuan tinggi, sedang dan rendah menjadi satu kelompok, kemudian disusun pula lembar observasi untuk diisi oleh observer pada saat proses pembelajaran berlangsung di setiap pertemuan.

2. Pelaksanaan

Kegiatan dalam pertemuan adalah sebagai berikut:

a. Guru melakukan tanya jawab dengan siswa tentang materi bangun datar

b. Menyampaikan tujuan dan prosedur pembelajaran yang dilaksanakan oleh siswa,

c. Meminta siswa membuat bangun datar persegi dan persegi panjang pada alat praga papan berpaku.

d. Setelah dibuat gambar pada alat praga papan berpaku siswa diminta menjelaskan sifat bangun tersebut dan menyebutkan bagiannya.

e. Guru menambahkan dan memperbaiki dari penjelasan siswa yang sudah mendemonstrasikan tadi

f. Guru melakukan evaluasi pada akhir pembajaran berupa tes soal uraian.

g. Guru bersama siswa bersama-sama menyimpulkan materi yang dibahas.

Berdasarkan kegiatan yang dilakukan ini, memang tidak begitu banyak hasil yang diharapkan, namun demikian, tindakan ini perlu dilakukan secara berulang-ulang dengan pertemuan-pertemuan selanjutnya sehingga siswa dapat mengerti bangun data persegi dan persegi panjang tanpa harus menghapal rumus dan mudah diterapkan dalam soal.

3. Penilaian hasil evaluasi

Nilai hasil evaluasi yang dibuat oleh guru misalnya berjumlah 5 soal yang masingmasing berhubungan dengan kompentensi dasar. Nilai rata-rata tersebut diperoleh dari jumlah diperoleh siswa dalam pertemuan peragaan aktivitas pembelajaran melalui papan berpaku.

Untuk menghitung tingkat pemahaman siswa dalam pembelajaran berbasis aktivitas melalui papan berpaku adalah sebagai berikut:

a. Penetapan jumlah siswa berkemampuan tinggi, sedang dan rendah. Misalnya siswa berkemampuan tinggi adalah bernilai $80-100$, siswa berkemampuan sedang bernilai $65-79$ dan siswa berkemampuan rendah adalah $20-64$. 
b. Penetapan jumlah nilai rata adalah jumlah nilai dibagi jumlah siswa.

c. Penetapan jumlah siswa berkemampuan tinggi diperoleh dari tabel nilai yang dibuat guru yakni jumlah siswa berkemampuan tinggi dibagi jumlah siswa maka akan diperoleh jumlah siswa berkemampuan tinggi.

d. Penetapan jumlah siswa berkemampuan sedang diperoleh dari tabel nilai yang dibuat guru yakni jumlah siswa berkemampuan sedang dibagi jumlah siswa maka akan diperoleh jumlah siswa berkemampuan sedang.

e. Penetapan jumlah siswa berkemampuan rendah diperoleh dari tabel nilai yang dibuat guru yakni jumlah siswa berkemampuan rendah dibagi jumlah siswa maka akan diperoleh jumlah siswa berkemampuan rendah.

Berdasarkan hasil tiga kemampuan tersebut dapat diobservasi dan dinilai dalam beberapa kali pertemuan yang setiap kali pertemuan dilakukan dengan jumlah siswa rendah, sedang dan tinggi. Misalnya dalam tiga kali pertemuan masih lebih banyak jumlah siswa berkemampuan rendah atau sedang, pada dapat dinilai tingkat kemampuan bangun datar, persegi panjang dan bangun lainnya siswa dalam kelas tersebut masih rendah atau sedang, maka perlu diberikan latihan khusus untuk meningkatkan tingkat kemampuan siswa dalam bidang studi matematika.

Pengukuran seperti ini harus terus ditingkatkan sehingga minat belajar siswa terhadap bidang studi matematika meningkat. Karena alat paraga dapat menjadi indikator untuk mengetahui tingkat kemampuan siswa terhadap matematika yang sangat monoton dan butuh perhatian khusus

\section{PENUTUP}

\section{Kesimpulan}

Dari pembahasan di atas, maka dapat disimpulkan bahwa terjadi interaksi edukatif bernilai normatif melalui pengajaran berbasis aktivitas dengan menerapkan penelitian tindakan kelas dengan papan berpaku, maka interaksi siswa dan guru dapat terjadi guru memberikan respon positif untuk siswa aktif dengan memperhatikan papan berpaku. Dari respon ini dapat diketahui siswa yang memiliki minat terhadap bidang studi matematika akan tingkat kemampuan tinggi sampai sedang. Artinya adanya respon positif yang diberikan guru sehingga terjadi komunikasi aktif antara guru dengan murid. Komunikasi inilah yang harus terus dibangun dalam pengajaran berbasis aktivitas. Tanpa komunikasi seperti ini maka tidak akan mungkin dapat tercapai minat belajar matematika yang dianggap monoton.

\section{Saran}

Dalam menciptakan iklim belajar yang aktif dan terjadi proses minat belajar berrbagai aktivitas dibutuhkan alat praga papan berpaku. Alat peraga ini yang dapat dijadikan perangkat dasar untuk terus aktif belajar matematika. Dengan respon seperti ini dapat dijadikan dasar respon untuk belajar bilangan, rumus matematika lainnya sehingga tidak timbul kejenuhan. Oleh karena itu, guru diharapkan dapat terus melakukan belajar matematika melalui papan berpaku secara berkala sehingga siswa benar seluruhnya memiliki tingkat kemampuan tinggi dan respon positif atas bidang studi matematika.

\section{DAFTAR PUSTAKA}

Dewa Ketut Sukardi. 2008. Motivasi Belajar dan Minat Belajar. Bandung: PT. Remaja Rosdakarya.

Djamarah, S.B. 2008. Psikologi Belajar. Jakarta: Airlangga

Hurlock. Alfred. M. 2007. Educational and Motivation. London: Irwin Press.

Purwanto. 2010. Bagaimana Belajar Matematika. Bandung: Remaja Rosdakarya 
Ruseffendi. 2007. Belajar dan Aktivitas Pengajaran. Jakarta: Indonesia Heritage Fuondation

Slameto. 2007. Belajar dan Psikologi. Jakarta: Penerbit Buku Kompas.

Suherman. 2007. Belajar Matematika. Bandung: Remaja Rosdakarya. 